Available online at http://www.anpad.org.br/bar

BAR, Curitiba, v. 8, n. 2, art. 4, pp. 168-184, Apr./June 2011

(cc) EY-NG

\title{
Using Social Networks Theory as a Complementary Perspective to the Study of Organizational Change
}

\author{
Manuel Portugal Ferreira * \\ E-mail address: manuel.portugal@ipleiria.pt \\ Instituto Politécnico de Leiria \\ Leiria, Portugal. \\ Sungu Armagan \\ E-mail address: sungu.armagan@business.fiu.edu \\ Florida International University \\ Miami, FL, USA.
}

* Corresponding author: Manuel Portugal Ferreira

Morro do Lena, Alto do Vieiro, Leiria, 2411-911, Portugal.

Copyright (C) 2011 Brazilian Administration Review. All rights reserved, including rights for translation. Parts of this work may be quoted without prior knowledge on the condition that the source is identified. 


\begin{abstract}
This paper contributes to the literature on organizational change by examining organizations as social entities embedded in inter-organizational networks. In contrast with extant research that focuses on macro environmental and internal factors to explain organizational change, we put forth the social network surrounding the firm as a major driver of any change process. Specifically, we examine organizational change as driven by the organizations' positions and relations in an interorganizational network, and advance a set of theory driven propositions on innovation, imitation, inertia, structural equivalence and structural positioning. Our conceptual discussion demonstrates that inter-organizational networks are important in complementing the macroenvironment and internal organizational factors for the study of organizational changes. We conclude with a discussion on normative implications for organizations and avenues for future research.
\end{abstract}

Key words: organizational change; social networks. 


\section{Introduction}

Organizational change has long been considered essential to understanding the dynamics of organizations (Aldrich, 1999). Organizations change to augment and leverage their competencies and update possible competitive advantages (Greenwood \& Hinings, 1996), especially when facing intense competition. Organizations also change to adjust to changing conditions in the environment. How firms deploy their strategies to react (adjust) or to undertake a pro-active action is one of the foci of strategic management research. For instance, firms may acquire other organizations to access knowledge not yet held (Ferreira, 2005), enter into an alliance to access new markets (Contractor \& Lorange, 1988) or generally seek new opportunities beyond their immediate competitive landscape through network forms of organization (Gulati, 1995, 1998).

The extant literature has examined how environmental factors, such as the societal demographic, technological customer demands, economic, legal and political situations and internal conditions, such as personnel decisions and organizational strategy, affect the initiation and implementation of organizational change (e.g., Gersick, 1991; Kimberly \& Quinn, 1984; Tushman \& Romanelli, 1985). However, much less attention has been paid to the role of social networks in organizational change, either as the actual trigger of the change or for the input, information, examples and so forth that they may bring in. By organizational change behaviors, we mean the organizational activities associated with initiating and implementing changes, but also the outcomes of those changes (see Weick \& Quinn, 1999).

Organizations may operate change in many ways. In this paper we focus specifically on the role of the organizations' networks - i.e., on the business and social relationships that firms hold. There is abundant research on the importance of social networks for firms' success (Dyer \& Singh, 1998; Gulati, 1995, 1998; Tenkasi \& Chesmore, 2003), and more generally on a variety of firms' economic behaviors (Granovetter, 1985). These relationships form structures that are capable of influencing firms' behaviors, including organizational change, by promoting or constraining their access to information, physical, financial and social resources, such as legitimacy (Baum, Calabrese, \& Silverman, 2000; Granovetter, 1985; Mohrman, Tenkasi, \& Mohrman, 2003).

The firms' social networks may be a major driver, and similarly a major barrier, of any organization change process. For instance, Tushman and Romanelli (1985, p. 177) noted that "networks of interdependent resource relationships and value commitment generated by its structure often prevent its being able to change", suggesting that an organization might be bound by other firms' expectations and needs. Some scholars have studied how interorganizational relations influence organizational learning and innovation (Powell, Koput, \& Smith-Doerr, 1996; Shan, Walker, \& Kogut, 1994), but change encompasses more than just learning. Notwithstanding, existing research falls short of clarifying the role of the firms' social networks for change endeavors.

In this paper, we examine the influence of the social networks on a focal firm's change behaviors by synthesizing the literature on organization change and on social networks. Specifically, we put forward the argument that the position and relations - particularly, connectedness, density, centrality and structural equivalence - of a firm in its network will affect the firm's change behaviors. The social network in which a focal firm is embedded either constrains or facilitates the firm's access to resources, information, legitimacy and power (Aldrich, 1979; Burt, 1992; Granovetter, 1985; Gulati, 1998; Rowley, 1997). In short, we contribute to the current understanding of the importance of social networks to initiate and operate organizational change, complementing the more frequent approaches based on an internally driven process or as the outcome of broader external environment influences.

This paper is structured as follows. First, we review the literature on organizational change, then on social networks. Third, we examine how networks may influence organizational change behaviors and develop a set of theory-driven propositions. We conclude with a discussion, implications for theory and practice and pointing out avenues for future research. 


\section{Organizational Change}

Organizational change may be analyzed from many angles. Following Damanpour (1988), we conceptualize organizational change as including many types of change, such as technological, administrative, strategic, and so forth. For instance, behaviorists study how employees' cognition and behaviors constrain organizational change (e.g., Gersick, 1989; Greve \& Taylor, 2000), and institutionalists emphasize how institutional norms maintain the stability of organizations (e.g., DiMaggio \& Powell, 1983; Hannan \& Freeman, 1984). Nonetheless, understanding how firms change requires the understanding of the underlying change process (Pettigrew, Woodman, \& Cameron, 2001). Weick and Quinn (1999) refer to the process of organizational change as encompassing three stages: the initiation, implementation and outcome of change. We briefly review these three stages.

The initiation refers to the causes, or triggers, of organizational change. Huber, Sutcliffe, Miller and Glick (1993) found five triggers of change: the macro-environment - such as those emerging from shifts in the economy, politics, technology or demography -, performance, characteristics of top managers, structure and strategy. More recently Greve and Taylor (2000) explored the role of innovations in catalyzing organizational change. Moreover, the initiation of change should be examined as to whether it is episodic - episodic change is mainly driven externally (Romanelli \& Tushman, 1994; Tushman \& O'Reilly, 1996) - or continuous - continuous change is caused by organizational instability and alert reactions to daily contingencies (Brown \& Duguid, 1991; Orlikowski, 1996). We add to these causes that the firms' social networks are a likely initiator of change.

The implementation refers to the process of carrying out organizational change. Firms may face some degree of inertia, or inability, to change as rapidly as the environment (Pfeffer, 1997) and extant research has attributed different motives for that inertia, such as the deep structures (Gersick, 1991) that, among others, refers to the organization and the activities that guarantee the firms' existence. An important barrier to change is the identity or culture of the organization, which will require a minor (first-order change) or major (second-order) change in the cognitive structure (Bartunek, 1993). Other sources of inertia include the routines (Gioia, 1992), top management tenure (Virany, Tushman, \& Romanelli, 1992), identity maintenance (Sevon, 1996), culture (Harrison \& Carroll, 1991), complacency (Kotter, 1996), institutional norms (DiMaggio \& Powell, 1983) and technology employed (Tushman \& Rosenkopf, 1992). The works by Levitt and March (1988), Leonard-Barton (1992) and Miller (1993) denote how a source of inertia may emerge from possible competency traps for organizations that have been successful and are less focused on observing the signals they need for change. Perhaps more fundamental are the internal constraints that hinder change or, as Romanelli and Tushman (1994, p. 1144) put it, organizations may resist change because they consist of a "system of interrelated organizational parts that are maintained by mutual dependencies among the parts and with competitive, regulatory and technological systems outside the organization that reinforce the legitimacy of managerial choices that produced the parts".

To overcome inertia and proceed with the implementation of change, some form of intervention or trigger is needed. Unlike episodic change, continuous change requires a somewhat different form of intervention in the form of redirecting of what is already underway (Argyris, 1990). However, to implement change, and most notably radical change, firms require financial, informational, physical and human resources (Aldrich, 1999). In an isolated firm the resources are either derived from within (Barney, 1991) or procured from markets (Williamson, 1985). In contrast, in a networked organization, the resources might be obtained from the network partners.

The outcome of organizational change is the effect of change. For instance, it may refer to whether a new technology replaces or only adjusts old systems in an organization. The outcome may be evaluated in terms of an improved likelihood of survival, growth or the firm's profitability postchange. Notwithstanding, not only will the implementation process impact the outcome of the 
organizational change, but also holding the required resources and prior experiences of change will facilitate the change.

To sum up, the phases of the change process - initiation, implementation and outcome - are central to studying organizational change behaviors and are fundamental when it comes to discussing the influence of the social network on organizational change. In the following section we define and discuss organizational social networks, providing some general principles and concepts of social network analysis.

\section{Social Networks}

Organizations are embedded in a wider external environment that shapes how and what organizations do (Aldrich, 1979; Scott, 1991). Several studies have described how firms are engaged in networks of relationships, for diverse purposes. For instance, the resource dependence theory proposes that organizations are not self-sufficient and need to engage in interdependent exchanges with other agents in their environment (Pfeffer \& Salancik, 1978). The institutional theory suggests that institutional norms greatly constrain organizational behaviors (DiMaggio \& Powell, 1983; Hannan \& Freeman, 1984; Meyer \& Rowan, 1977). The literature on strategic alliances advocates that firms form alliances with suppliers, distributors, banks and competitors to gain access to such resources as capital, information, knowledge, technology, social endorsement and legitimacy to create and maintain a competitive advantage (Gulati, 1995, 1998; Stuart, Hoang, \& Hybels, 1999; Walker, Kogut, \& Shan, 1997).

In this paper, we follow Lauman, Galaskiewicz and Marsden's (1978, p. 458) definition of social network as

a social system in which a finite set of organizations (e.g., suppliers, distributors, financial institutions, universities, governments) directly or indirectly connect to each other by various social relationships (e.g., strategic alliance, interlocking, personal relationship, affiliation) and whose structural pattern will constrain or facilitate member organizations' behaviors through various mechanisms (e.g., information flow, knowledge sharing, resource complementary).

A social network is thus a social structure composed of firms or individuals that are connected in specific patterns and are interdependent. The social networks research examines relations among organizations and argues that organizations' economic behaviors are embedded and dependent on their social relationships (Aldrich \& Whetten, 1981; Granovetter, 1985; Mizruchi \& Galaskiewicz, 1993).

There is little insight to be gained in restating that network or inter-organizational relationships are a vital part of the environment for modern organizations (Dyer \& Singh, 1998; Kraatz, 1998; Park, 1996; Uzzi, 1996). It is also well understood that organizational adaptation is crucial to success in the context of continuous, sometimes dramatic, environmental changes. However, the effects that social networks have on organization change are somewhat less understood, although it seems reasonable to sustain that inter-organizational relationships have a vital influence on driving firms to change and on how change is implemented (Kraatz, 1998; Mohrman et al., 2003; Tenkasi \& Chesmore, 2003; Uzzi, 1996). Moreover, the extant research has piled evidence that most organizations are located in widely differing networks of directly and indirectly linked organizations through a variety of relationships with different purposes, and that the networks may be strategically managed and reconfigured according to the firms' life cycle and needs (Ferreira, Serra, \& Santos, 2010; Hite \& Hesterly, 2001). Two classic examples of these social networks are found in the textile industry cluster in northern Italy and in the plastic moulding cluster in Portugal, where firms form complex links with each other through a wide array of family and business relations, social club memberships, and community ties (Ferreira, Tavares, \& Hesterly, 2006; Wasserman \& Faust, 1994). 
A focal firm needs to establish relationships with multiple organizations to obtain resources, institutional legitimacy, information, and so forth (see Gulati \& Gargiulo, 1999; Hite \& Hesterly, 2001). These ties connecting firms may take various forms, from contractual agreements such as a strategic alliances (Gulati, 1995; Stuart et al., 1999) to the more informal personal relationships (Macaulay, 1963) binding individuals and firms. The network ties between organizations may significantly influence the firm's actions and outcomes. Table 1 summarizes the main principles and assumptions in social network analyses.

Table 1

Network Analysis Principles and Assumptions

\begin{tabular}{ll}
\hline \multicolumn{1}{c}{ Principles } & \multicolumn{1}{c}{ Assumptions } \\
\hline $\begin{array}{l}\text { - Behavior is interpreted in terms of structural } \\
\text { constraints on activity rather than in terms of inner } \\
\text { forces within units. }\end{array}$ & $\begin{array}{l}\text { - Actors and their actions are viewed as } \\
\text { interdependent units. }\end{array}$ \\
- Analyses focus on the relations between units. & - Relational ties between actors are channels for the \\
& transfer of resources. \\
- Concerned with how the pattern of relationships & - Network models focusing on individuals view the \\
among multiple actors jointly affects network & $\begin{array}{l}\text { network structure as providing opportunities for and } \\
\text { constraints on individual actions. }\end{array}$ \\
members' behaviors. & $\begin{array}{l}\text { - Network models conceptualize structure (whether } \\
\text { - Analytical methods deal directly with the patterned } \\
\text { relational nature of social structure. }\end{array}$ \\
\end{tabular}

Note. Source: Adapted from Rowley, T. (1997). Moving beyond dyadic ties: a network theory of stakeholder influences (p. 893). Academy of Management Review, 22(4), 887-910.

\section{Networks, macro-environmental and internal factors}

In this paper we examine why social networks might influence organization change. The social networks are herein suggested to complement the macro-environmental and internal approaches in explaining organizational change. These three approaches highlight rather distinct change mechanisms. The macro-environmental factors suggest that organizations should proactively initiate changes, such as innovations, to reshape their marketplace (Tushman \& O'Reilly, 1996). For example, computer processor manufactures invest heavily in $R \& D$ to lead technological change and not be overtaken by competitors. Moreover, firms should also attempt to predict the future direction of environmental shifts and react proactively (Porras \& Silver, 1991) to reduce potential negative effects caused by discontinuous, or radical, environmental changes. On the other hand, the internal factors suggest that organizations focus on addressing internal structures, including cognitive or cultural ones, and procedures to facilitate organizational changes (Gersick, 1991; Woodman, 1989). For instance, organizations need to develop an organizational culture that embraces change and deploy flexible organizational structures to embrace adaptability.

The social networks analysis recommends that organizations develop ties to other firms in a network to make the most of their positions and relations (Gulati \& Gargiulo, 1999). At least to some level, firms seem to be better at constructing and perhaps at manipulating their networks than at dealing with macro-environmental shifts. For example, Hite and Hesterly (2001) argued that firms strategically redesign the composition of their networks to fulfill resource needs, when moving from the emergence to the early growth stage. Baum et al. (2000) found that start-ups configure their networks to provide efficient access to diverse information and capabilities with minimum costs of redundancy, conflict and complexity. These studies suggest that network members are possible sources of a variety of physical, social, financial and market resources. We summarize some of the 
main differences between the three approaches in Table 2. The differences highlighted in Table 2 partly explain why the study of social networks will provide somewhat different prescriptive implications for organizational change.

Table 2

Contrasting Macro-environmental, Internal and the Social Network's Influence on Organization Change

\begin{tabular}{|c|c|c|c|}
\hline Dimensions & Macro-environmental & Internal & Inter-organizational \\
\hline Level of analysis & Macro-level & $\begin{array}{l}\text { Organizational, group, } \\
\text { individual level }\end{array}$ & Organizational network \\
\hline $\begin{array}{l}\text { The role of } \\
\text { organizations in } \\
\text { response to changes }\end{array}$ & $\begin{array}{l}\text { Organizations respond } \\
\text { passively to } \\
\text { environmental changes } \\
\text { without too much latitude } \\
\text { to manipulate } \\
\text { environments. } \\
\text { Notwithstanding, } \\
\text { organizations can } \\
\text { reasonably predict } \\
\text { environmental changes } \\
\text { and take proactive } \\
\text { actions. }\end{array}$ & $\begin{array}{l}\text { Organizations have complete } \\
\text { control over internal changes } \\
\text { in terms of radicalness, } \\
\text { frequency and duration. } \\
\text { However, outcomes of } \\
\text { internal changes also depend } \\
\text { on external factors. }\end{array}$ & $\begin{array}{l}\text { The degree of control that } \\
\text { organizations have over } \\
\text { changes initiated inside } \\
\text { the network depends on } \\
\text { their positions and } \\
\text { relations in networks. }\end{array}$ \\
\hline The scope of influence & $\begin{array}{l}\text { Changes in macro- } \\
\text { environments usually } \\
\text { have an impact on the } \\
\text { wide range of } \\
\text { organizations, for } \\
\text { example, an industry. }\end{array}$ & $\begin{array}{l}\text { Internal changes generally } \\
\text { have a direct impact on } \\
\text { organizations' subunits. } \\
\text { Without the existence of } \\
\text { interorganizational ties, these } \\
\text { changes will be confined } \\
\text { within organizations. }\end{array}$ & $\begin{array}{l}\text { Changes taking place } \\
\text { inside a network will } \\
\text { mainly be confined } \\
\text { within the network. The } \\
\text { range of influence } \\
\text { depends on the whole } \\
\text { configuration of the } \\
\text { network. An } \\
\text { organization's position } \\
\text { and relations in the } \\
\text { network define how } \\
\text { much influence it can be } \\
\text { subject to. }\end{array}$ \\
\hline Change mechanisms & $\begin{array}{l}\text { Change is initiated by } \\
\text { macro-factors that lie } \\
\text { outside of the } \\
\text { organizations' control. } \\
\text { The influence will be } \\
\text { directly felt by } \\
\text { organizations. Some } \\
\text { changes will diffuse } \\
\text { through } \\
\text { interorganizational } \\
\text { interdependence. }\end{array}$ & $\begin{array}{l}\text { Organizations usually initiate } \\
\text { organizational change by } \\
\text { themselves and implement } \\
\text { change in a top-down fashion. } \\
\text { Administrative power plays } \\
\text { an important role. }\end{array}$ & $\begin{array}{l}\text { Two types of change } \\
\text { mechanisms: } \\
\text { - Possibility to change } \\
\text { a. Imitation } \\
\text { b. Diffusion } \\
\text { c. Resource accessibility } \\
\text { d. Diverse and new } \\
\text { information } \\
\text { e. Power leverage } \\
\text { - Pressure to change } \\
\text { a. Interdependence } \\
\text { b. Division of labor }\end{array}$ \\
\hline Representative studies & $\begin{array}{l}\text { Huber et al. (1993); } \\
\text { Romanelli and Tushman } \\
\text { (1994); Tushman and } \\
\text { Anderson (1986) }\end{array}$ & $\begin{array}{l}\text { Gersick (1989); Schein } \\
\text { (1996); Morrison and } \\
\text { Milliken (2000) }\end{array}$ & Powell et al. (1996) \\
\hline
\end{tabular}


Therefore, the networks are likely to be change-initiating triggers on a more regular and continuous base than external and possibly internal factors. Networks often exert coercive collective pressure impelling the organization to adapt. Partly, that is because network relationships create interdependence among organizations (Park, 1996), as firms compromise autonomy in exchange for access to some sort of strategic resources (Ferreira et al., 2006; Hite \& Hesterly, 2001). Moreover, changes in one organization may lead to a domino effect in a network, and the more so the stronger and denser the ties connecting firms (Tenkasi \& Chesmore, 2003).

\section{The Role of Social Networks in Organizational Change}

How do organizational networks influence the initiation, implementation and outcomes of change? In this section we discuss five ways in which social networks influence organization change: innovation, imitation, inertia, structural equivalence and structural positioning.

\section{Innovative dynamism and change: looking at connectedness}

The density of a network is perhaps the most widely used construct of connectedness (Friedkin, 1984) and group cohesion ${ }^{(1)}$ (Blau, 1977) among network members. The density of the network in which a firm is embedded is likely to affect change processes. In denser networks there are more ties among firms, and these ties serve as channels for the faster flow of information concerning markets, best practices and institutional norms (Meyer \& Rowan, 1977), innovation, technology, and so forth (Tenkasi \& Chesmore, 2003). Connecting tightly with other organizations, a focal organization has more channels to detect both the opportunities and the modifications occurring in its environment.

Innovative dynamism and access to new knowledge are often considered important triggers of organizational change (Weick \& Quinn, 1999). Powell et al. (1996) noted the importance of inter-firm interfaces, particularly close and strong connections, in transferring tacit knowledge. In fact, the strong ties perspective (Krackhardt, 1992; Uzzi, 1996) postulates that frequent interaction, intimacy, trust and reciprocity facilitate the flow of information and knowledge resources among firms and may be better suited for the change implementation process. Park (1996), using a resource-based view, stressed that the transfer of tacit knowledge from other organizations is critical for building a competitive advantage. Brown and Duguid (1991), Porter (1987), Powell et al. (1996) and Ibarra (1993), among, others, have shown that interconnectedness plays a critical role in organizational innovation processes, adoption and diffusion. According to Park (1996, p. 799) "the open-ended, relational features of networks, therefore, greatly enhance the ability to transmit and learn new knowledge and skills for an innovation". Astley and Fombrun (1983) have noted how technological innovations were carried out mainly by a complex and wide range of inter-firm networks in the telecommunication industry. Shan et al. (1994) found that the number of ties between start-ups and established firms is positively related to their innovative output in the biotechnology industry. Hence, it seems reasonable to suggest that organizational change is fuelled by access to new opportunities and resources, namely knowledge resources, that feed innovations that are likely to be more abundant in denser networks.

Proposition 1. An organization in a denser organizational network is likely to have more frequent innovations driving organizational change.

\section{Imitation and change: sparseness and density of the network}

The denser the network, the more likely it is that we may observe more intensive imitation which is another mechanism potentially driving the firms to change. In other words, denser networks may drive institutional conformity among members (DiMaggio \& Powell, 1983; Meyer \& Rowan, 1977) and over time firms will come to increasingly resemble one another. In a study of mimetic processes, Galaskiewicz and Wasserman (1989), for example, noted that organizations in the same 
network mimicked one another's behaviors to gain legitimacy. For instance, using interlocking directors may lead them to mimic each other (Haunschild, 1993), namely regarding corporate governance practices, but arguably a set of procedures, norms and organizational formats. The importance of imitation is reflected in Sevon's (1996, pp. 60-61) statement that "every theory of organizational change must take into account the fact that leaders of organizations watch one another and adopt what they perceive as successful strategies for growth and organizational structure". In short, imitation in a network might be the trigger for organizational change, as organizations have access to and use each other as referents.

Membership in a network creates strong interdependence between organizations, particularly when strong ties exist and will pressure organizations to change in line with other organizations. These are isomorphic pressures whereby organizations tend to come to resemble each other over time. A stronger density of connectedness facilitates firms to understand the purpose and what needs to change (Cook, 2001) while improving the odds of the implementation itself and of success (Krackhardt, 1994) In short, by connecting with other organizations, an organization is subject to not only the changes initiated by itself but also to the changes initiated by other organizations (Aldrich \& Whetten, 1981). In a richly joined system, the frequency of changes will likely be higher and any external influence that has a disturbing influence on one link of the system might eventually affect the entire chain of links, due to the large number of links through which outside events flow into the chain.

Proposition 2. An organization in a denser organizational network is likely to experience change through imitation more often than an organization in a sparser network.

\section{Inertia and change: interdependency among firms}

Interdependency among subunits is a main source of inertia against change (Porras \& Silver, 1991). The discussions on alignment (Pfeffer, 1998), configurations (Miller, 1990) and cultural inertia (Tushman \& O'Reilly, 1996) offer some insights into this line of argument. When interrelations among firms are abundant (or dense) and strong, it will take a larger intervention to realign them.

Firms do not exist in an isolated world. In a dense network, hazards in a firm may bear a negative impact on other network members. It is likely that the social norms of the network may pressure a firm to follow other firms' changes and fulfill the others' expectations (Gersick, 1991). In addition, the larger information and communication channels among network members will expose the firms to new strategies or management practices used by other organizations, increasing the likelihood of imitation. In contrast, organizations in sparser networks will be more isolated and hold less abundant channels for communications and diffusion both within and across the network and will not endeavor to imitate either these pressures or the abundance of opportunities stemming from other organizations.

The density of the network is likely to affect the duration of organizational changes. Organizations in denser networks are more interconnected and interdependent, whereby an eventual change in an organization will also influence other organizations with which it is tied. For example, the introduction of a new product by a firm will require adaptations by the suppliers (e.g., production facilities) and the sellers (e.g., marketing strategies). Thus, changes in one firm will likely have implications for other firms up - and down-wards in the value chain, requiring connected firms to make complementary changes. Hence, in a network, any organizational change is imprisoned by the partners' ability to accompany change. Thus, it seems reasonable to suggest that a change in a focal organization will take longer to implement when engaged in a network. Indeed Simon (1962) argued that it takes longer for a system with a strong network of links between elements to reach a stable state.

Proposition 3. An organization in a denser network is likely to take a longer period of time to implement and complete change than in a sparser network. This period will be longer the higher the interdependence among the firms in the network. 


\section{Structural equivalence and change: a matter of similarity}

Structural equivalence, also referred to as structural isomorphism (Winship, 1988), occurs when two (or more) actors have identical ties to and from all other actors in the network (Borgatti \& Everent, 1992; Wasserman \& Faust, 1994). It is likely that in a network some firms occupy similar structural positions due to the complex interconnections we have discussed. It is thus probable that not only the organizations' structural positions influence their behaviors, but also that structurally equivalent organizations behave similarly. For instance, evidence for similarity of behaviors is found in Coleman, Katz and Menzel's (1957) conclusion that while a physician is likely to adopt and prescribe a new drug using information gathered from manufacturers and published studies, the likelihood increases once he is aware that other physicians have already adopted that same drug. Kilduff (1993) also found that people in structurally equivalent positions tend to have similar perceptions.

Firms in structurally equivalent positions may perceive each other as similar and act similarly. Several studies have argued that social positions such as structural equivalence drive social homogeneity (e.g., Burt, 1987; Hartman \& Johnson, 1990). Following this line of argument, we may suggest that if one firm adopts a new course of action, a different strategy, an innovation, and so forth, its structural equivalents are likely to behave isomorphically, taking identical actions. A general proposition may thus be formulated as:

Proposition 4. An organization's actions for change are likely to be influenced by those of a structural equivalent to others operating in the same network.

\section{Structural positioning and change: firm's centrality}

The structural positioning of the firm, namely the centrality (Freeman, 1979), in the network matters. Positioning refers to the location of a focal "actor" relative to other firms in the network (Wasserman \& Faust, 1994). According to Ibarra (1993), the position of an actor, be it an individual or an organization, determines its status, the extent of involvement in relationships and its visibility to the others. Burt (1992) argued that different positions in a network provide different degrees of access to, and control over, valued resources.

An organization's centrality is a core construct in structural positioning. Centrality has to do with how close a focal actor is to all the other actors in the network. An actor is central if it is involved in communication between other two actors (Freeman, 1979). Central organizations serve as communication channels between organizations transferring resources, information and clients (Aldrich \& Whetten, 1981). As Aldrich and Whetten (1981, p. 397) stated "organizations in a central position have easy access to information about potential innovations and by manipulating the flow of information, as well as exerting influence, can direct the allocation of a population's resources in an innovative direction". The central firms broker the information flows (Wasserman \& Faust, 1994) and the centrality provides its holder with more access to updated information concerning external environmental changes. Moreover, central organizations have the most ties to other organizations in the network and are recognized by others as a major channel of relational information. In contrast, peripheral actors are not as active in the relational process (Wasserman \& Faust, 1994).

The central organizations have access to a variety of resources pooled together by the network, which provide them with more chances to innovate than peripheral organizations (Ibarra, 1993). Moreover, the position itself exerts some pressure on the central organization to change if it wishes to maintain a competitive advantage. Due to the broader access to information, it is more likely that the central organization will accurately predict the future directions of environmental shifts and be able to proactively adapt. Porras and Silver (1991, p. 54) stated that: "creating a better fit between the organization's capabilities and its current environmental demands, or promoting changes that help the organization to better fit predicted future environments". 
Proposition 5. A more central organization is likely to change more frequently than a less central organization.

The central actor is the pacesetter, and it is likely that the central firm initiates change. In some instances the central firm is the referent model that others imitate (Haveman, 1993). Due to its control over information and physical resources, the central organization has more power to coordinate other organizations that are interdependent on each other (Pfeffer \& Salancik, 1978).

In addition to accessing more resources, which will help the central firm change frequently, firms may draw some power by occupying central positions (Mizruchi \& Galaskiewicz, 1993). The environmental shifts carry uncertainties and risks that are to a large extent have to do with the fact that there is limited information about them. An argument could be made that firms in firms in the periphery could actually start adopting the incremental changes and as these prove their effectiveness they could then be passed on gradually to the neighboring units (Krackhardt, 1997; Tenkasi \& Chesmore, 2003). However, it is more likely that firms that access more information and resources are better able to predict the future direction of changes, possibly being able to proceed with implementing both smaller incremental changes to continuously keep pace with environments and the larger-scale changes that encompass multiple systems of the organization. These changes are more likely to be successfully implemented by central, rather than peripheral, organizations.

Proposition 6. A more central organization is likely to change more successfully than a less central organization.

\section{Discussion and Concluding Remarks}

We have noted that social networks influence organizations' change behaviors in many respects. Organizational change may be scrutinized through macro-environmental, internal and also network factors. Focusing on inter-firm relationships may yield refreshing explanations for organizational change. The normative prescriptions for practitioners using a network perspective are likely to complement those prescribed by a focus on the macro-environmental and internal organizational factors.

Studying the impact of social networks on organizational change might be extended in a number of important ways. For instance, future research may seek to delimit the boundaries of a network to better understand which firms have more influence on any change process, and which firms are most influenced by another's actions. How are firms indirectly connected to the source of change influenced? Furthermore, for simplification purposes we did not delve deeply into hybrid governance forms, such as joint ventures, equity-based strategic alliances and interlocking directorates. However, examining these types of inter-firm interfaces may help account for imitation, inertia and who firms use as referent others.

The examination of constructs such as density or centrality of organizations in a network may be improved upon when we include the types of ties that bind firms. The most widely studied characteristic of ties is strong/weak ties. The strength of a tie is given by "a combination of the amount of time, the emotional intensity, the intimacy (mutual confiding) and the reciprocal services which characterize the tie" (Granovetter, 1973, p. 1361). The strength of a tie may be also determined by the frequency of interaction among firms and, more importantly, that firms connected by strong ties tend to be similar in various ways (Granovetter, 1973; Haveman, 1993; Lorrain \& White, 1971). Friedkin (1984) and Collins (1988) noted that a network tightly connected through strong ties would create homogeneity among members, whereby organizations are less prone to seeking and receiving new information from outside the network. These organizations are probably lee less likely to initiate change, and will be more isolated from other firms (Collins, 1988). 
Future research might even observe how organizational change may vary concerning the magnitude and scope (Gersick, 1991) of change, or to how fundamental an organizational change is and to what extent the activities, structures, and so forth, post-change differ from those previously established (Watzlawick, Weakland, \& Fisch, 1974). Some scholars have distinguished between incremental and radical change to reflect that while incremental change is manifest in small and gradual adjustments, which consist essentially of variations on the same theme (Nadler, Shaw, \& Walton, 1995), radical change entails a substantial departure, divergence, revolution (Weick \& Quinn, 1999), quantum change (Miller \& Friesen, 1984) or transformation (Porras \& Silver, 1991). While the radical changes tend to involve the entire organization, often leading to the shattering of the established pattern of behaviors, the incremental changes are small in magnitude, narrow in scope, and do not change the structures of the firm (Gersick, 1991).

An additional avenue for future research could delve into the nature of the network, whose impact on any change process may be non negligible. This could involve, for instance, exploring the strength of the ties binding firms, cohesion and trust, the purpose of the network, and so forth. In brief, it may not only be the network but the type of network or other characteristic that is idiosyncratic to the network that comes into play when we assess the influence of social networks on organizational change.

How radical an organizational change is, is central to describing organizational dynamics (Tushman \& Romanelli, 1985). The radicalness of the change will likely influence the outcome of the change, and it seems reasonable to suggest that a firm that endeavors and implements radical changes more appropriately will likely outperform competitors. Future research might explore whether an organization in a denser network will be more likely to experience radical change than an organization in a sparse network.

We have contributed to the theme by establishing a set of propositions on how networks impact organizational change. By observing the organization's network we are able to place it in its social milieu. For practitioners, we have suggested that it is fundamental to build the firm's network strategically. The network is likely to be the primary driver of the ability to change, whether adapting or responding pro-actively to environmental shifts. Firms need to invent, learn, adapt to customers' demands, become more efficient and provide higher quality goods and services if they wish to succeed.

To conclude, social networks seem to matter when it comes to organization change. The social network members are vehicles for the flow of a variety of social, physical and financial resources and information. The network members are also closer to other firms that seek to imitate them, but they also form a protective womb that leads to inertia and the inability to proceed with change. Whatever the specific mechanisms considered, the social network in which a firm operates is a fundamental driver of organizational change.

\section{Received 24 March 2010; received in revised form 16 August 2010.}

\section{Note}

\footnotetext{
${ }^{1}$ Actually, density only reflects the number of relationships (or ties) that exist among a set of organizations in the network, without disclosing details on the nature of the ties (Wasserman \& Faust, 1994).
}

\section{References}

Aldrich, E. (1979). Organizational environment. Englewood Cliffs, NJ: Prentice Hall. 
Aldrich, E. (1999). Organizational evolving. London: Sage Publication Ltd.

Aldrich, H. E., \& Whetten, D. (1981). Organization-sets, action-sets, and networks: making the most of simplicity. In P. C. Nystrom \& W. H. Starbuck (Eds.), Handbook of Organizational Design (pp. 385-408). New York: Oxford University Press.

Argyris, C. (1990). Overcoming organizational defenses. Facilitating organizational learning. Boston: Allyn and Bacon.

Astley, W., \& Fombrun, C. (1983). Collective strategy: social ecology of organizational environments. Academy of Management Review, 8(4), 576-587. doi:10.2307/258259

Barney, J. (1991). Firm resources and sustained competitive advantage. Journal of Management, 17(1), 99-120. doi: 10.1177/014920639101700108

Bartunek, J. (1993). The multiple cognitions and conflicts associated with second order organizational change. In J. Murnighan (Ed.), Social psychology in organizations: advances in theory and research (pp. 322-349). Englewood Cliffs, NJ: Prentice Hall.

Baum, J., Calabrese, T., \& Silverman, B. (2000). Don't go it alone: alliance network composition and startups' performance in Canadian biotechnology. Strategic Management Journal, 21(3), 267294. doi: 10.1002/(SICI)1097-0266(200003)21:3<267::AID-SMJ89>3.0.CO;2-8

Blau, P. (1977). Inequality and heterogeneity. New York: Free Press.

Borgatti, S., \& Everett, M. (1992). Notions of position in social network analysis. Sociological Methodology, 22, 1-35.

Brown, S., \& Duguid, P. (1991). Organizational learning and communities-of-practice: toward a unified view of working, learning, and innovation. Organization Science, 2(1), 40-57. doi: 10.1287/orsc.2.1.40

Burt, R. (1987). Social contagion and innovation: cohesion versus structural equivalence. American Journal of Sociology, 92(6), 1287-1335. doi:10.2307/2779839

Burt, R. (1992). Structural holes: the social structure of competition. Cambridge, MA: Harvard University Press.

Coleman, J., Kantz, E., \& Menzel, H. (1957). The diffusion of an innovation among physicians. Sociometry, 20(4), 253-270.

Collins, R. (1988). Theoretical sociology. New York: Harcourt Brace Jovanovich.

Contractor, F., \& Lorange, P. (1988). Cooperative strategies in international business. Lexington, MA: Lexington Books.

Cook, J. (2001). Social networks: a primer. Durham, NC: Duke University.

Damanpour, F. (1988). Innovation type, radicalness, and the adoption process. Communication Research, 15(5), 545-567. doi: 10.1177/009365088015005003

DiMaggio, P., \& Powell, W. (1983). The iron cage revisited: Institutional isomorphism and collective rationality in organizational fields. American Sociological Review, 48(2), 147-160.

Dyer, J., \& Singh, H. (1998). The relational view; cooperative strategy and sources of interorganizational competitive advantage. Academy of Management Review, 23(4), 660-679. doi: $10.2307 / 259056$ 
Ferreira, M. P. (2005). Building and leveraging knowledge capabilities through cross border acquisitions: the effect of the MNC's capabilities and knowledge strategy on the degree of equity ownership acquired. Unpublished doctoral dissertation, University of Utah, Salt Lake City, UT, USA.

Ferreira, M. P., Serra, F., \& Santos, J. (2010). The international entrepreneurial firms' social networks. Cadernos Ebape, 8(1), 133-145. doi: 10.1590/S1679-39512010000100009

Ferreira, M. P., Tavares, A., \& Hesterly, W. (2006). A new perspective on parenting spin-offs for cluster formation. In F. Fai \& E. Morgan (Eds.), Managerial Issues in International Business (pp. 67-84). Hampshire: Palgrave MacMillan.

Freeman, L. (1979). Centrality in social networks conceptual clarification. Social Networks, 1(3), 215239. doi:10.1016/0378-8733(78)90021-7

Friedkin, N. (1984). Structural cohesion and equivalence explanations of social homogeneity. Sociological Methods \& Research, 12(3), 235-261. doi: 10.1177/0049124184012003001

Galaskiewicz, J., \& Wasserman, S. (1989). Mimetic processes within an interorganizational field: an empirical test. Administrative Science Quarterly, 34(3), 454-479.

Gersick, C. (1989). Marking time: predictable transitions in producing intentional change in organizations. Academy of Management Journal, 32(2), 274-309

Gersick, C. (1991). Revolutionary change theories: a multilevel exploration of the punctuated equilibrium paradigm. Academy of Management Review, 16(1), 10-36. doi: 10.2307/258605

Gioia, D. (1992). Pinto fires and personal ethics: a script analysis of missed opportunities. Journal of Business Ethics, 11(5-6), 379-389. doi: 10.1007/BF00870550

Granovetter, M. (1973). The strength of weak ties. American Journal of Sociology, 78(6), 1360-1380. doi: $10.1086 / 225469$

Granovetter, M. (1985). Economic action and social structure: a theory of embeddedness. American Journal of Sociology, 91(3), 481-510.

Greenwood, R., \& Hinings, C. (1996). Understanding radical organizational change: bringing together the old and the new institutionalism. Academy of Management Review, 21(4), 1022-1054. doi: $10.2307 / 259163$

Greve, H., \& Taylor, A. (2000). Innovations as catalysts for organizational change: shifts in organizational cognition and search. Administrative Science Quarterly, 45(1), 54-80.

Gulati, R. (1995). Social structure and alliance formation patterns: a longitudinal analysis. Administrative Science Quarterly, 40(4), 619-652. doi: 10.2307/2393756

Gulati, R. (1998). Alliance and networks. Strategic Management Journal, 19(4), 293-317. doi: 10.1002/(SICI)1097-0266(199804)19:4<293::AID-SMJ982>3.0.CO;2-M

Gulati, R., \& Gargiulo, M. (1999). Where do interorganizational networks come from? American Journal of Sociology, 104(5), 1439-1494. doi:10.2307/2990941

Hannan, M., \& Freeman, J. (1984). Structural inertia and organizational change. American Sociological Review, 49(2), 149-164.

Harrison, J., \& Carroll, G. (1991). Keeping the faith: a model of cultural transmission in formal organization. Administrative Science Quarterly, 36(4), 552-582. 
Hartman, A., \& Johnson, J. (1990). Formal and informal group communication structures: an examination of their relationship to role ambiguity. Social Networks, 12(2), 127-151. doi:10.1016/0378-8733(90)90002-Q

Haunschild, P. (1993). Interorganizational imitation: the impact of interlocks on corporate acquisition activity. Administrative Science Quarterly, 38, 564-592.

Haveman, H. (1993). Follow the leader: mimetic isomorphism and entry into new markets. Administrative Science Quarterly, 38(4), 593-627.

Hite, J., \& Hesterly, W. (2001). The evolution of firm networks: from emergence to early growth of the firm. Strategic Management Journal, 22(3), 275-286. doi: 10.1002/smj.156

Huber, G., Sutcliffe, K., Miller, C., \& Glick, W. (1993). Understanding and predicting organizational change. In G. Huber \& W. Glick (Eds.), Organizational Change and Redesign (pp. 215-265). New York: Oxford Univ. Press.

Ibarra, H. (1993). Network centrality, power, and innovation involvement: determinants of technical and administrative roles. Academy of Management Journal, 36(3), 471-501.

Kilduff, M. (1993). Deconstructing organizations. Academy of Management Review, 18(1), 13-31.

Kimberly, J., \& Quinn, R. (1984). New futures, the challenge of managing corporate transitions. Homewood, IL: Dow Jones-Irwin.

Kotter, J. (1996). Leading change. Boston, MA: Harvard Business School Press.

Kraatz, M. (1998). Learning by association? Interorganizational networks and adaptation to environmental change. Academy of Management Journal, 41(6), 621-643.

Krackhardt, D. (1992). The strength of strong ties: the importance of philos in organizations. In N. Nohria \& R. Eccles (Eds.), Networks and organizations (pp. 216-239). Boston: Harvard Business School Press.

Krackhardt, D. (1994). Graph theoretical dimensions of informal organizations. In K. Carley \& M. Prietula (Eds.), Computational organization theory (pp. 216-239). Boston: Harvard Business School Press.

Krackhardt, D. (1997). Organizational viscosity and diffusion of controversial innovations. Journal of Mathematical Sociology, 22(2), 177-199. doi: 10.1080/0022250X.1997.9990200

Laumann, E., Galaskiewicz, J., \& Marsden, P. (1978). Community structures as interorganizational linkages. In R. Turner, J. Coleman, \& R. Fox (Eds.), Annual Review of Sociology (Vol. 4, pp. 455-484), Palo Alto: Annual Reviews.

Leonard-Barton, D. (1992). Core capabilities and core rigidities: a paradox in managing new product development. Strategic Management Journal, 13(S1), 111-125. doi: 10.1002/smj.4250131009

Levitt, B., \& March, J. (1988). Organizational learning. Annual Review of Sociology, 14, 319-340.

Lorrain, F., \& White, H. (1971). Structural equivalence of Individuals in social networks. Journal of Mathematical Sociology, 1, 49-80.

Macaulay, S. (1963). Non-contractual relations in business: a preliminary study. American Sociological Review, 28(1), 55-67.

Meyer, J., \& Rowan, B. (1977). Institutional organizations: formal structure as myth and ceremony. The American Journal of Sociology, 83(2), 340-363. doi: 10.1086/226550 
Miller, D. (1990). Organizational configurations: cohesion, changes, and prediction. Human Relations, 43(8), 771-789. doi: 10.1177/001872679004300805

Miller, D. (1993). The architecture of simplicity. Academy of Management Review, 18(1), 116-138.

Miller, D., \& Friesen, P. (1984). A longitudinal study of corporate life cycle. Management Science, 30(10), 1161-1183.

Mizruchi, M., \& Galaskiewicz, J. (1993). Networks of interorganization relations. Sociological Methods and Research, 22(1), 46-70. doi: 10.1177/0049124193022001003

Mohrman, S., Tenkasi, R., \& Mohrman, A., Jr. (2003). The role of networks in fundamental organizational change. The Journal of Applied Behavioral Science, 39(3), 301-323. doi: $10.1177 / 0021886303258072$

Morrison, E., \& Miliken, F. (2000). Organizational silence: A barrier to change and development in a pluralistic world. The Academy of Management Review, 25(4), 706-725.

Nadler, D., Shaw, R., \& Walton, A. (1995). Discontinuous change. San Francisco: Josey-Bass.

Orlikowski, W. (1996). Improvising organizational transformation overtime: a situated change perspective. Information System Research, 7(1), 63-92. doi: 10.1287/isre.7.1.63

Park, S. (1996). Managing an interorganizational network: a framework of the institutional mechanism for network control. Organization Studies, 17(5), 795-824. doi: 10.1177/017084069601700505

Pettigrew, A., Woodman, R., \& Cameron, K. (2001). Studying organizational change and development: challenges for future research. Academy of Management Journal, 44(4), 697-713.

Pfeffer, J. (1997). New directions for organization theory. New York: Oxford University Press.

Pfeffer, J. (1998). The human equation. Boston: Harvard Business School.

Pfeffer, J., \& Salancik, G. (1978). The external control of organizations: a resource dependence perspective. New York: Harper and Row.

Porras, J., \& Silver, R. (1991). Organization development and transformation. Annual Review of Psychology, 42, 51-78.

Porter, M. (1987). From competitive advantage to corporate strategy, Harvard Business Review, 65(3), 43-59.

Powell, W., Koput, K., \& Smith-Doerr, L. (1996). Interorganizational collaboration and the locus of innovation: networks of learning in biotechnology. Administrative Science Quarterly, 41(1), 116-145. doi:10.2307/2393988

Romanelli, E., \& Tushman, M. (1994). Organizational transformation as punctuated equilibrium: an empirical test. Academy of Management Journal, 37(5), 1141-1166. doi: 10.2307/256669

Rowley, T. (1997). Moving beyond dyadic ties: a network theory of stakeholder influences. Academy of Management Review, 22(4), 887-910.

Schein, E. (1996). Kurt Lewin's change theory in the field and in the classroom: notes toward a model of managed learning. Systems Practice, 9(1), 27-47. doi: 10.1007/BF02173417

Scott, W. (1991). Unpacking institutional arguments. In W. Powell \& P. DiMaggio (Eds.), The New Institutionalism in Organizational Analysis (pp. 164-182). Chicago: University of Chicago Press. 
Sevon, G. (1996). Organizational imitation in identity transformation. In B. Czarniawska \& G. Sevon (Eds.), Translating Organizational Change (pp. 49-68). New York: Walter de Gruyter.

Shan, W., Walker, G., \& Kogut, B. (1994). Interfirm cooperation and start-up innovation in the biotechnology industry. Strategic Management Journal, 15(5), 387-394. doi: $10.1002 / \mathrm{smj} .4250150505$

Simon, H. (1962, December). The architecture of complexity. Proceedings of the American Philosophical Society, 106(6), 467-482.

Stuart, T., Hoang, H., \& Hybels, R. (1999). Interorganizational endorsements and the performance of entrepreneurial ventures. Administrative Science Quarterly, 44(2), 315-349.

Tenkasi, R., \& Chesmore, M. (2003). Social networks and planned organizational change: the impact of strong network ties on the effective change implementation and use. The Journal of Applied Behavioral Science, 39(3), 281-300. doi: 10.1177/0021886303258338

Tushman, M., \& Anderson, P. (1986). Technological discontinuities and organizational environments. Administrative Science Quarterly, 31(3), 439-465.

Tushman, M., \& O'Reilly, C. (1996). The ambidextrous organizations: managing evolutionary and revolutionary change. California Management Review, 38(4), 1-23.

Tushman, M., \& Romanelli, E. (1985). Organizational revolution: a metamorphosis model of convergence and reorientation. In L. Cummings \& B. Staw (Eds.), Research in organizational behavior (pp. 171-222). Greenwich, CT: JAI Press.

Tushman, M., \& Rosenkopf, L. (1992). Organizational determinants of technological change: towards a sociology of technological evolution. Research in organizational behavior (pp. 311-347). Greenwich, CT: JAI Press.

Uzzi, B. (1996). The sources and consequences of embeddedness for the economic performance of organizations: the network effect. American Sociological Review, 61(4), 674-698. doi: $10.2307 / 2096399$

Virany, B., Tushman, M., \& Romanelli, E. (1992). Executive succession and organization outcomes in turbulent environments: an organizational learning approach. Organization Science, 3(1), 72-91. doi: $10.2307 / 2635299$

Walker, G., Kogut, B., \& Shan, W. (1997). Social capital, structural holes and the formation of an industry network. Organization Science, 8(2), 109-125. doi:10.2307/2635305

Wasserman, S., \& Faust, K. (1994). Social network analysis: methods and applications. Cambridge: Cambridge University of Press.

Watzlawick, P., Weakland, J., \& Fisch, R. (1974). Change. New York: Norton.

Weick, K., \& Quinn, R. (1999). Organizational change and development. Annual Review of Psychology, 50(1), 361-386. doi:10.1146/annurev.psych.50.1.361

Williamson, O. (1985). The economic institutions of capitalism: firms, markets, relational contracting. New York: Free Press; London: Collier Macmillan.

Winship, C. (1988). Thoughts about roles and relations: an old document revisited. Social Networks, 10(3), 209-231. doi:10.1016/0378-8733(88)90013-5

Woodman, R. (1989). Organizational change and development: new areas for inquiry and action. Journal of Management, 15(2), 205-228. doi: 10.1177/014920638901500205 